\title{
A CRENÇA NO PRINCÍPIO (OU MITO) DA IMPARCIALIDADE JUDICIAL
}

\section{重 Bárbara Gomes Lupetti Baptista}

\section{Palavras-Chave \\ imparcialidade judicial / pesquisa empírica / operação Lava Jato}

\section{SUMÁRIO}

1. Introdução; 2. O discurso do "deverser": a imparcialidade judicial na legislação; 3. Os diversos sentidos e representações atribuídos à imparcialidade judicial: "a imparcialidade é um exercício de comportamento...é um mito"; 4. O superego da magistratura: entre "ser" e "parecer ser" imparcial; 5. Entre a neutralidade e a imparcialidade; 6. "Fazer mágica" para "fazer justiça"; 7. Considerações Finais; 8. Referências.

\section{Resumo}

Este texto pretende discutir o princípio da imparcialidade judicial e seus dilemas, com base em pesquisa empírica realizada no Tribunal de Justiça do Estado do Rio de Janeiro, entre os anos de 2008 e 2012. Trata-se de descrever os sentidos e as representações que os próprios operadores do

Doutora em Direito pela Universidade Gama Filho (2012). Mestre em Direito pela Universidade Gama Filho (2007). Professora Adjunta da Faculdade de Direito da Universidade Federal Fluminense. Professo ra do Programa de Pós-graduação Stricto Sensu em Direito da Universidade Veiga de Almeida. Pesquisadora do INCT-InEAC/UFF. sistema de justiça brasileiro, especialmente magistrados, atribuem ao conceito de imparcialidade. A ignição para a retomada do tema neste artigo decorre da divergência que se instalou no campo jurídico sobre a postura do ex-Juiz Sergio Moro na condução dos processos da operação Lava Jato, especialmente após as repercussões do vazamento de suas conversas com o coordenador da força-tarefa, Deltan Dallagnol, divulgadas pelo periódico The Intercept, a partir de junho de 2019. A pesquisa explicita que as práticas judiciárias e as decisões judiciais são orientadas por percepções subjetivas e sensos particularizados de justiça, que se revelam nas interpretações pessoais dos magistrados sobre os significados da lei, dos fatos e das provas produzidas no processo judicial. E que, entre o dever de parecerem imparciais e o fato de serem humanos, os magistrados transitam em um sistema de crenças de sua própria imparcialidade, construído discursivamente pelo campo do direito, e que funciona como uma categoria estruturante do sistema judiciário, que desloca e centraliza no magistrado, o poder de interpretar e de decidir, no caso concreto, o que significa "fazer justiça". 


\section{THE BELIEF IN THE PRINCIPLE (OR MYTH) OF JUDICIAL IMPARTIALITY}

\section{Bárbara Gomes Lupetti Baptista²}

\section{Keywords}

judicial impartiality / empirical research / Car Wash operation / Lava Jato operation

\section{Abstract}

This paper aims to discuss the principle of judicial impartiality and its dilemmas, based on empirical research conducted at the State Court of Rio de Janeiro, between 2008 and 2012. It is a description of the senses and representations that the professionals within the Brazilian justice system, especially judges, attribute to the concept of impartiality. The ignition for the resumption of the theme in this article stems from the divergence that has taken place in the legal field regarding the posture of former Judge Sergio Moro in conducting the proceedings of the "Lava Jato" (Car Wash) operation, especially after the repercussions of the leakage of his talks with the task force coordinator, Deltan Dallagnol, published by The Intercept as of June 2019. The research explains that judicial practices and judicial decisions are guided by subjective perceptions and particular senses of justice, which are revealed in the judges' personal interpretations of the meanings of the law, the facts and the evidence produced in the judicial process. And that, between the duty to appear to be impartial and the fact that they are human, judges move into a belief system of their own impartiality, discursively constructed by the field of law, and that functions as a structuring category of the judicial system, which displaces and centralizes in the judge the power to interpret and decide - in the present case, what it means to "do justice". 


\section{INTRODUÇÃO}

Este artigo se insere no contexto de um dossiê, que pretende discutir questões de interesse do campo da Antropologia do Direito. Logo, trata-se de pensar sobre o tema da imparcialidade judicial, a partir de uma perspectiva empírica, ou seja, não dogmática; distanciada, portanto, de juízos de valor ou opinativos, como costuma acontecer em textos jurídicos tradicionais, e que privilegia o direcionamento do olhar para a realidade das práticas judiciárias, tal como elas se apresentam no cotidiano forense, partindo da premissa de que o Direito não se esgota no campo normativo.

Nos termos de Lévi-Strauss (1976), o nível da observação foi o que me conduziu nesta pesquisa e que serviu de regra principal para a abordagem que pretendo articular. Em suas palavras, "todos os fatos devem ser exatamente observados e descritos, sem permitir que os preconceitos teóricos alterem sua natureza e sua importância." (Lévi-Strauss, 1976, p. 14).

A imparcialidade judicial, tema deste artigo, consiste, grosso modo, em um princípio de direito processual, ${ }_{4}^{4}$ que se materializa na ausência de vínculos subjetivos do magistrado com o processo, caracterizando-se por seu dever de se manter distante e desinteressado do processo o suficiente

\footnotetext{
3 O uso de parênteses no texto tem a finalidade de destacar as referências bibliográficas e o uso de colchetes, cunho didático e explicativo e, eventualmente, para destacar as omissões feitas em meio às citações.

${ }^{4}$ No campo do Direito, os princípios funcionam como orientações ou mandamentos. São normas de conteúdo aberto, direcionadas ao Juiz no exercício de interpretação das leis. "A nosso ver, princípios gerais do direito são enunciações normativas de valor genérico, que condicionam e orientam a compreensão do ordenamento jurídico, quer para a sua aplicação e integração, quer para a elaboração de novas normas. Cobrem, desse modo, tanto o campo da pesquisa pura do Direito quanto o de sua atualização prática [...] eles são eficazes independentemente do texto legal [...]". (Reale, 2004, p. 304-305). "[...] Os princípios gerais do direito são cânones que não foram ditados, explicitamente, pelo elaborador da norma, mas estão contidos de forma imanente no ordenamento jurídico [...] os princípios não tem existên cia própria, estão ínsitos no sistema, mas é o juiz que, ao descobri-los, Ihes dá força e vida. (Diniz, 1994, p. 419).
}

para conduzi-lo com isenção, sem privilegiar nenhuma das partes. É visto como um princípio, alçado à categoria de garantia processual, de justiça para as partes.

Nessa linha, este texto pretende discutir o princípio da imparcialidade judicial e seus dilemas, com base em pesquisa empírica, de cunho etnográfico, realizada no Tribunal de Justiça do Estado do Rio de Janeiro, entre os anos de 2008 e 2012, por ocasião do meu doutoramento em Direito (Lupetti Baptista, 2013).

Naquela circunstância, de elaboração da tese de doutorado, observei julgamentos e audiências cíveis; analisei processos judiciais que envolviam o afastamento de magistrados por motivos de impedimento ou suspeição na condução de processos sob sua responsabilidade; e entrevistei, formal e informalmente, advogados, servidores, magistrados, promotores de justiça, defensores públicos e jurisdicionados.

Para a elaboração deste texto, tive de fazer um recorte da pesquisa mais ampla, que foi realizada para a tese de doutorado.

Aqui, pretendo tratar, apenas, de um, dentre os distintos aspectos do tema da imparcialidade judicial, que está relacionado com os seus significados e representações, traçados a partir das entrevistas que pude realizar durante o trabalho de campo, nas quais me foi dito, recorrentemente, que um dos maiores dilemas da atuação dos magistrados está no difícil equilíbrio de viver entre o dever de parecerem imparciais e o fato de serem humanos. Logo, cuida-se de tentar descrever "o ponto de vista dos nativos", no caso, prioritariamente, dos próprios magistrados, sobre os sentidos, representações e dramas [como eles pró- 
prios, por vezes, me descreviam] do seu dever de imparcialidade, lido como necessário distanciamento das partes, para evitar contaminação de subjetividades que exijam a sua interdição e para evitar que julguem os processos com base em suas convicções pessoais, afastando-se do conteúdo da lei.

Nos termos de Geertz (1998, p. 86), tentei pensar e problematizar: "como é possível chegar a conhecer a maneira como um nativo pensa, sente e percebe o mundo?" e, a partir disso, entender como é, para os próprios juízes, experimentar o dever de ter de ser imparcial; e os paradoxos e dilemas decorrentes dessa ambiguidade. E aqui, pontuo, nos próprios termos de Geertz (1998), que, quando ele menciona a proposta do antropólogo, ele não quer, com isso, dizer que, efetivamente, se conhecerá a maneira como um nativo pensa, sente e percebe o mundo, porque isso seria quase impossível, pelo menos para o intelecto, mas sim compreender aquilo que eles dizem e pensam sobre o que fazem e como representam e dão sentido às suas práticas.

Devo dizer que, a essa altura, resgatar [ou mesmo ressuscitar] o tema ["antigo"] da minha tese de doutorado para este dossiê foi uma ideia oriunda da intensidade com que o assunto vem sendo tratado e debatido na sociedade e também no campo do Direito, por ocasião, especialmente, da Operação Lava Jato, iniciada em meados do ano de 2014 e retratada como sendo a maior investigação de corrupção e lavagem de dinheiro do Brasil, com inúmeras repercussões, diferenciadas e singulares, inclusive, a prisão do ex-Presidente Lula, seguida da "Vaza-Jato", representada pelo vazamento de conversas divulgadas pelo jornalista americano Glenn Greenwald, do periódico virtual The Intercept, a partir de junho de 2019, que evidenciam a relação íntima existente entre o ex-juiz Sérgio Moro e o promotor Deltan Dallagnol, no âmbito da Operação Lava Jato.

Decidi retomar o tema da minha tese de doutorado, portanto, porque, afinal, ele nunca esteve tão em voga na mídia e nos debates da sociedade [embora seja velho conhecido de quem tem intimidade com as práticas judiciárias brasileiras]. E, mais do que isso, também me pareceu oportuno reanimá-lo, porque tenho ficado estupefata com o espanto dos cidadãos brasileiros e, mais ainda, de colegas pesquisadores, que parecem ver, abismados, pela primeira vez, situações que se mostraram, durante a minha pesquisa, tão corriqueiras e tão características [ao mesmo tempo, tão arcaicas] de nosso sistema de justiça.

As reações de perplexidade diante do comportamento do ex-juiz Sérgio Moro sugerem, equivocadamente, que a sua postura ativista - e, portanto, comprometida com o seu senso de justiça particular - seria inédita, quando, na verdade, os dados empíricos que pretendo compartilhar demonstram certa regularidade nesse modus operandi de se "fazer justiça". Para ilustrar, um dos magistrados que eu entrevistei, aposentado, me disse em certa ocasião: "Eu sempre quis ser um juiz humano e, para isso, eu não tinha apego à Lei. Quando era necessário, deixava a Lei de lado. Quando a minha intuição do 'justo' me motivava, eu fazia a justiça.".

Nesse quadro, a principal ignição para a retomada desse assunto, além do que já disse acima, foi justamente observar o exercí- 
cio pleno da discordância que caracteriza o mundo dos juristas, embebidos pela lógica do contraditório5 (Amorim, 2006; Duarte \& Iorio Filho, 2015; Kant de Lima, 2010), no que se refere, particularmente, à atuação do ex-Juiz Sergio Moro logo que foram vazadas as suas conversas com o Promotor Deltan Dallagnol.

A divergência que se instalou sobre a postura do ex-Juiz diante do caso e a pergunta que todos se viram obrigados a responder, posicionando-se contra ou a favor do comportamento do ex-Juiz e questionando se ele teria sido parcial ou imparcial, me fez pensar que o assunto da imparcialidade judicial merecia ser reavivado.

Entre os que se manifestavam entendendo, ou opinando, que o ex-Juiz foi claramente parcial e aqueles que não vislumbravam nada de comprometedor nas conversas divulgadas e na relação entre o ex-Juiz e o Promotor do caso, posicionei-me eu mesma, colocando-me a pensar sobre o quanto poderia ser interessante reviver minha pesquisa de campo e mapear, ali, no passado, pistas para tentar entender um pouco do que está acontecendo no presente. E é um pouco das distintas visões sobre a imparcialidade judicial, que pretendo descrever aqui.

\footnotetext{
5ant de Lima (2010), Amorim (2006) e Duarte e lorio Filho (2015) vêm destacando esta questão e expressando que a origem desta lógica, do contraditório, tanto quanto registra a história do saber jurídico, ja era encontrada nos exercícios de contradicta realizados nas primeiras universidades que ministraram o ensino jurídico durante a Idade Média, particularmente na Itália, berço europeu deste ensino (Berman, 2006). Por ser constituída de argumentação infinita, a lógica do contraditório necessita da manifestação de uma autoridade que a interrompa para que seja dada continuidade aos procedimentos judiciais nos tribunais brasileiros. No caso, o juiz. E na ausência da autoridade formalmente constituída, o contraditório prossegue, sempre descartando a possibilidade de a comunicação tornar-se consensual. A característica essencial dessa lógica, a despeito de sua estrutura aberta, encontra-se na supressão da possibilidade de os participantes alcançarem concordância, sejam eles partes do conflito, operadores jurí dicos ou doutrinadores, o que sugere ausência de consenso interno ao saber produzido no próprio campo e, no limite, falta de consenso externo, manifesto na distribuição desigual da justiça entre os jurisdicionados pelas mesmas leis que Ihes são aplicadas e pelos mesmos tribunais que Ihes oferecem a prestação jurisdicional. Por sermos, no campo do direito, socializados na lógica contraditória escolástica, seja no processo, seja na produção da dogmática jurídica, somos muito pouco afeitos à lógica da argumentação, voltada para consensualizações provisórias e sucessivas.
}

O intuito do texto passa longe de responder à pergunta que me serviu de gatilho acerca do comportamento parcial ou imparcial do ex-Juiz. Ou mesmo de retratar ou problematizar a operação Lava Jato em si. Este não é, definitivamente, o objeto deste texto, que não pretende ser um estudo de caso. Trata-se, apenas, de problematizar - a partir do caso - os diferentes sentidos atribuídos pelos meus interlocutores ao conceito de imparcialidade.

Sendo assim, o texto está sistematizado de forma a tratar, primeiro, do discurso normativo sobre o tema da imparcialidade judicial e, depois, descrever as falas e representações dos entrevistados acerca do tema, problematizando, ao final, a partir da "Vaza-Jato", os sentidos atribuídos pelos operadores do sistema de justiça ao dever de imparcialidade dos magistrados.

\section{O DISCURSO DO “DEVER-SER": A IMPARCIALIDADE JUDICIAL NA LEGISLAÇÃO}

A imparcialidade judicial é incorporada pela doutrina processual, tanto civil, quanto penal, como condição do legítimo exercício da função jurisdicional, constituindo-se como "essência da jurisdição" (Galdino, 2011, p. 540).

O significado discursivo do princípio da imparcialidade judicial está atrelado à ideia de que as partes têm direito ao julgamento da lide por um juiz imparcial, que conduza o processo de forma desinteressada. Ou seja, os juízes não podem ter interesse pessoal em relação ao resultado do processo.

Leonardo Greco, processualista civil, assevera que "o direito de acesso à justiça é o direito a um julgamento por um juiz imparcial, ou seja, um juiz equidistante das partes e dos interesses a ele submetidos, que vai 
examinar a postulação no intuito exclusivo de proteger o interesse de quem tiver razão". (Greco, 2005, p. 231)

Aury Lopes Júnior (2016, p. 88), processualista penal, menciona que a imparcialidade é um "princípio supremo do processo" e, como tal, imprescindível para o seu normal desenvolvimento e obtenção do reparto social justo.

No Código de Processo Civil (Brasil, 2015), a garantia de imparcialidade está prevista nos artigos 144 ao 148; e no Código de Processo Penal (Brasil, 1940), nos artigos 252 ao 256, que tratam das causas de impedimento e de suspeição que autorizam o afastamento do magistrado da condução do processo.

Na Declaração Universal dos Direitos Humanos - DUDH (ONU, 1948), o princípio da imparcialidade está previsto no artigo X: "toda a pessoa tem direito, em plena igualdade, a uma justa e pública audiência por parte de um tribunal independente e imparcial, para decidir seus direitos e deveres ou fundamento de qualquer acusação criminal contra ela.".

$\mathrm{Na}$ Convenção Americana de Direitos Humanos - Pacto de San José da Costa Rica (OEA, 1969), a previsão de um juiz imparcial encontra-se no artigo 8. $^{\circ}$, que trata das garantias judiciais, $n{ }^{\circ} \mathrm{l}$ :

1. Toda pessoa terá o direito de ser ouvida, com as devidas garantias e dentro de um prazo razoável, por um juiz ou Tribunal competente, independente e imparcial, estabelecido anteriormente por lei, na apuração de qualquer acusação penal formulada contra ela, ou na determinação de seus direitos e obrigações de caráter civil, trabalhista, fiscal ou de qualquer outra natureza. (OEA, 1969)

No Código de Ética da Magistratura Nacional (CNJ, 2008), aprovado na $68^{a}$ Sessão Ordinária do Conselho Nacional de Justiça, do dia 06 de agosto de 2008, a imparcialidade está prevista no artigo $8^{\circ}$.

O magistrado imparcial é aquele que busca nas provas a verdade dos fatos, com objetividade e fundamento, mantendo ao longo de todo o processo uma distância equivalente das partes, e evita todo o tipo de comportamento que possa refletir favoritismo, predisposição ou preconceito. (CNJ, 2008)

Ou seja, a ideia central de imparcialidade, na visão doutrinária, corresponde ao desejo de equidistância [no sentido de distanciamento] do Juiz, em relação às partes, traduzindo-se na idealização da igualdade processual, na medida em que os magistrados não podem preferir ou privilegiar uma parte em prejuízo da outra.

\section{OS DIVERSOS SENTIDOS E REPRESENTAÇÕES ATRIBUÍDOS À IMPARCIALIDADE JUDICIAL: "A IMPARCIALIDADE É UM EXERCÍCIO DE COMPORTAMENTO...É UM MITO".}

Um dos principais incômodos de minha atividade profissional como advogada, antes mesmo de ingressar no mundo acadêmico, sempre foi o abismo que separa o mundo do discurso jurídico e o das práticas judiciárias. Comumente, nos mais diversos campos de atuação profissional, não vemos correspondência entre o dever-ser que consta nos manuais de direito e o que, de fato acontece, no mundo das práticas processuais. Para atuar como advogados, precisamos deter um conhecimento empírico, que não está disponibilizado nos livros. Um saber empíri- 
co, um saber-fazer, que não nos é ensinado, mas que nos é exigido, para fazer o processo acontecer.

Por causa disso, me aproximei da antropologia cultural e essa circunstância me permitiu empreender pesquisas empíricas sobre o direito, para tentar compreender melhor o mundo das práticas judiciárias, sem me restringir às idealizações normativas sobre o sistema de justiça.

A pesquisa sobre a imparcialidade judicial seguiu, portanto, esse caminho: de problematizar e de estranhar o discurso normativo.

O discurso sobre a imparcialidade judicial como garantia processual e como pressuposto de validade do processo é tão recorrente quanto as críticas sobre a sua impossibilidade e falta de concretude.

Por isso mesmo, um dos instrumentos de pesquisa que utilizei durante o trabalho de campo realizado para a tese de doutorado - que vou destacar neste artigo - foi entrevistar operadores do direito, especialmente magistrados, para entender qual era o seu ponto de vista sobre o ônus da imparcialidade em sua atividade jurisdicional.

Entrevistei cerca de 80 interlocutores. Em sua maioria, através de entrevistas abertas [sem estrutura prévia ou roteiro] e gravadas.

Eu simplesmente agendava a entrevista ou chegava sem aviso prévio e informava sobre o meu interesse de pesquisa, identificando-me e informando que o trabalho ensejaria a minha tese de doutorado e que eu não identificaria os interlocutores.

O meu questionamento aos interlocutores, especialmente magistrados, era o mais amplo possível, normalmente, materializado na narrativa de que eu estava estudando o princípio da imparcialidade judicial e curiosa para entender o seu ponto de vista sobre o mesmo, assim como, na prática, como eles lidam com o dever de "ter de ser imparcial". $E$, se possível, solicitava que me contassem casos, histórias ou suas memórias pessoais sobre situações que os tenham incomodado ou exigido seu afastamento do processo, como controle de sua eventual parcialidade.

Curioso que, muito frequentemente, os meus interlocutores expressavam logo no começo das entrevistas: "eu não acredito em imparcialidade" ou "você sabe que a imparcialidade é uma coisa que não existe, né?" E também categorizavam-na como sendo "mito", "quimera", "fábula", "utopia", "fantasia". Ao passo que, ao final das entrevistas, costumavam dizer que, apesar de a imparcialidade "não existir", é preciso sustentar a sua crença, porque "se o judiciário assume que o juiz não consegue ser imparcial, o sistema vai falir. Acaba o sistema.". "As pessoas têm que acreditar que ali tem um juiz imparcial, senão ninguém mais vai ao Judiciário para resolver seus problemas; vão resolver tudo sozinhos".

Essa dicotomia me chamou especial atenção e me parece fazer muito sentido quando direcionamos o olhar para o caso do ex-juiz Sérgio Moro e sua atuação na operação Lava Jato, bem como para a recepção de seu comportamento na sociedade civil e no campo profissional e acadêmico do direito.

Segundo os dados empíricos revelaram, mais do que existir de fato, a imparcialidade se constitui como crença. E guarda uma ambiguidade: de um lado, manter vivo o seu discurso serve para ocultar a sua eventual inexistência e, de outro, manter vivo o seu discurso produz efeitos para os destina- 
tários do sistema de justiça.

Trata-se de uma crença, construída discursivamente pelo campo do direito [constituído por legisladores, doutrinadores e profissionais], que é configurada como uma categoria estruturante do sistema, sem a qual o Judiciário "fecharia as suas portas", como me disse mais de um magistrado durante a pesquisa.

$\mathrm{E}$, independentemente de ser possível de se atingir, a imparcialidade sobrevive enquanto crença, logo, independente da realidade concreta. Existe e se legitima como discurso, satisfazendo-se em se reproduzir mais enquanto discurso do que prática. Porque isso é importante para legitimar o sistema de justiça e fazer com que os cidadãos creiam em sua efetividade.

Ela é um dever inerente à função, mas, ao mesmo tempo, um mito, uma quimera, uma fábula ou uma utopia que os magistrados [e os profissionais do sistema de justiça] devem se esforçar para manter viva.

Uma juíza que entrevistei, cuja frase intitula este tópico do artigo, disse-me: "a imparcialidade é um exercício de comportamento, uma coisa que você vai treinando com o tempo. É muito difícil! E é um mito...".

Uma advogada me disse: "A imparcialidade é a certeza que tem o cidadão de que a causa submetida ao juiz não vai ser decidida em razão de sua classe social, cor da sua pele, da sua ideologia política. O juiz que vai julgar não tem interesse nisso. Ele é imparcial.".

Ouvi, com muita frequência, reverberar a crença de que: "a imparcialidade tem que existir, porque sem ela as pessoas não vão mais vir ao Judiciário. Vão resolver seus problemas sozinhas, com suas próprias mãos".
Ou: "as pessoas precisam acreditar que suas vidas serão julgadas por juízes imparciais. Isso tem a ver com a confiança no sistema.".

E tem a ver com "O poder simbólico", de Pierre Bourdieu (1989), que descreve a crença e o poder das palavras como força de ação:6

[...] o poder simbólico como poder de construir o dado pela enunciação, de fazer ver e fazer crer, de confirmar ou de transformar a visão do mundo, e deste modo, a ação sobre o mundo, e portanto o mundo; poder quase mágico que permite obter o equivalente daquilo que é obtido pela força [...] entre os que exercem o poder e os que lhe estão sujeitos, quer dizer, isto é, na própria estrutura do campo em que se reproduz e se produz a crença o que faz o poder das palavras e das palavras de ordem, poder de manter a ordem ou a de subverter é a crença na legitimidade das palavras e daquele que as pronuncia, crença cuja produção não é da competência das palavras. (Bourdieu, 1989, p. 14 e 15)

No caso da imparcialidade, o poder do discurso chama a atenção.

Os interlocutores expressavam, claramente, a ambiguidade de a imparcialidade, ao mesmo tempo, existir e não existir.

Eu não acredito na imparcialidade, mas não posso dizer isso. Porque acreditar que ela existe conforta...dá segurança. É uma falsa segurança, mas é necessária. Todo mundo tem que acreditar que o processo vai ser julgado por alguém que é impar-

5 Foucault (2005), por sua vez, também apontara que o discurso interfere na realidade; aliás, ele está, inclusive, na ordem das leis. Aqui, não se pretende aprofundar a discussão, mas apenas pontuar que o discurso seria constitutivo da realidade e produziria, como o poder, inúmeros saberes. Discursos e práticas estão, portanto, implicados mutuamente. E, nesse sentido, a crença consolidada na reverberação do discurso sobre a imparcialidade, produz efeitos práticos. 
cial, que vai cumprir a lei. Senão, é o fim do Judiciário. Se as pessoas pararem de acreditar que serão julgadas conforme a lei, o processo e por um juiz imparcial, isso tudo acaba.

Daí a comoção causada quando se suscita, no caso da Vaza Jato, uma relação de extrema proximidade entre juiz e promotor, a revelar o comprometimento da imparcialidade que causa invalidade processual.

A mera desconfiança de sua inexistência provoca também a desconfiança no sistema de justiça e a diluição da crença dilui o próprio sistema, de modo que mantê-la viva é manter vivo o próprio sistema de justiça.

Um interlocutor, advogado experiente, me disse:

Só consigo ver imparcialidade como dogma. Ou como crença. Como algo real, eu não consigo. Mas, eu não acho ruim saber que a imparcialidade só existe enquanto dogma, que o juiz é um ser humano e, portanto, vai errar, vai eventualmente prejulgar, vai se influenciar, Nada disso acho ruim. Acho que é assim mesmo.

Um desembargador me disse:

A nossa decisão só será respeitada se formos imparciais e isso é o que segura o sistema. Você não pode esvaziar esse discurso. É isso que sustenta tudo. Se você for estudar o conceito de jurisdição, você vai ver que o que sustenta a existência do Judiciário é a imparcialidade, que está ligada a confiança das pessoas a se dirigirem até aqui e transferirem a nós o poder de decidir as suas vidas. Sem isso, o que que a gente vai fazer? O nosso trabalho é esse. Sem isso, o sistema não tem legitimidade nenhuma e não se sustenta.
Jeveaux, (1999) tratando da crença da imparcialidade, diz que ela cumpre o papel simbólico de oferecer segurança e dar garantias às partes:

[...] o que realmente importa é que, no âmbito do processo, os participantes acreditem (creiam) que possuem as mesmas oportunidades para influenciar o convencimento do magistrado, e que este não ofereça motivos ou desconfiança a qual lado vai pender [...] para os não participantes a crença também vale, ante a expectativa de que, se vierem a estar na mesma situação, terão as mesmas chances. Só que isto não vale exclusivamente para dentro do processo, mas também, e principalmente, para que todos da comunidade acreditem que todo aquele aparato está realmente ali, à sua disposição, somado a outros tantos que, por assim dizer, estabilizam as suas expectativas e forcejam a ilusão de que, idealmente considerados, virão em seu socorro acaso necessário. (Jeveaux, 1999, p. 83 e 84)

Bourdieu (1983) fala de um mercado linguístico, em seu texto intitulado "O que falar quer dizer". E, ao tratar do assunto, destaca que, neste mercado do discurso, o locutor coloca os seus produtos linguísticos à venda para que alguém os compre. Ou seja, aquele que cria o discurso tem de considerar as condições de aceitabilidade desse discurso. No caso da imparcialidade judicial, os magistrados constroem a crença e os crentes alimentam-na [quando submetem os seus conflitos ao sistema de justiça]. Criam-se condições propícias para que a crença se estabeleça como "verdade".

Foucault também explica isso em sua ordem do discurso, como já dito aqui (Foucault, 2005). A legitimidade do discurso e da coisa 
pronunciada é dada por aqueles que o constroem, mas também por aqueles a quem o discurso se dirige, a tal ponto que em toda a sociedade a produção do discurso é controlada, selecionada, organizada e redistribuída.

Discurso e verdade não estão necessariamente vinculados. Foucault (2005) mostra que o discurso não precisa ser verdadeiro em si, porque é ele que produz verdade. $O$ discurso cria verdade. Ele é realizado ao ser dito.

No caso do judiciário, dizer e reproduzir que a imparcialidade existe é tentar fazê-la existir. Preservar a imparcialidade enquanto dogma é necessário. Afinal, o efeito do discurso é o que produz a sua materialidade.

Certamente, no caso do sistema de justiça, manter firme e alimentar a crença na imparcialidade é mais essencial para os operadores do que para os próprios cidadãos. De todo modo, sem a legitimidade destes, a crença perde a sua potência.

Foucault (1971), em outra obra que trata da linguagem, também dissera que o que importa não é o que o discurso diz nem o que ele acha que diz, mas o que ele faz. Ou seja, o conhecimento que ele é capaz de produzir.

Nesse sentido, me pareceu interessante trazer este assunto não pelo fato, de per si, de a imparcialidade se reproduzir enquanto crença, mas sim para explicitar que sustentar esta crença sustenta algo [o poder do sistema de justiça]. Ou seja, existe sempre um já-dito anterior. Como menciona Foucault (1971), todo o discurso manifesto repousa secretamente sobre um já-dito. O discurso formulado já está articulado em um meio-silêncio que lhe é prévio (Foucault, 1971). A crença na imparcialidade [fomentada pelos operadores do sistema de justiça] sustenta [ou alimenta], de alguma, a crença [dos cidadãos] no Judiciário. Ou, talvez, melhor: produz a confiança imprescindível à existência do sistema jurisdicional e, nesse sentido, o estrutura.

Um advogado que entrevistei me falou:

[...] o judiciário depende diretamente da imparcialidade. Por isso que eu sempre digo que não basta o juiz ser imparcial, ele tem que atuar de modo imparcial, mostrar isso, porque é isso que vai gerar e manter a confiança dos jurisdicionados na imparcialidade do poder judiciário. É imperativo que as pessoas vejam uma atuação imparcial.

E ratifico o discurso da crença nas palavras de um magistrado, muito contundente:

Então, quando eu digo que não existe imparcialidade é porque não tem como, mas o discurso tem que existir sempre para dar segurança jurídica para a sociedade. Para as pessoas se sentirem seguras. A sociedade tem que saber, tem que acreditar que vai encontrar um juiz imparcial, porque senão isso coloca em risco a tranquilidade social. Se você sabe que aquele juiz que vai te julgar não é imparcial, você não vai querer que ele julgue o processo. Você não vai deixar sua vida na mão daquele juiz e, então, você vai querer resolver seu problema de outro jeito, vai resolver a situação do seu jeito. E a pacificação? Questão de segurança jurídica. Vai ser a lei do mais forte. O juiz tem que ser isento para você e para a outra parte. Para os dois. Se não for assim, vou lá e resolvo logo dando um tiro na cara do sujeito. Eu mesmo faço a minha justiça. Se eu sentir que o juiz vai estar do lado da outra parte, pra que que eu vou me submeter? Não vou. 
O Judiciário, portanto, para manter a crença da imparcialidade, esconde a realidade e constrói um mito. Talvez por isso mesmo, tenha sido tão comum, ouvir de meus interlocutores, que a "imparcialidade é uma meta, um exercício". "A gente trabalha para atingi-la.".

\section{O SUPEREGO ${ }^{7}$ DA MAGISTRATURA: ENTRE "SER" E "PARECER SER" IMPARCIAL}

A necessidade de se sustentar discursivamente a crença na imparcialidade judicial redunda, portanto, no esforço de torná-la visível, aparente.

Ouvi de muitos interlocutores nas entrevistas que realizei, que: "assim como ocorre com a mulher de césar, não basta ser imparcial, é preciso parecer imparcial". ${ }^{8}$

Para o campo do Direito, a legitimidade do sistema se sustenta em "parecer imparcial".

Talvez por isso mesmo, ou seja, por ter posto em xeque a crença no mito da imparcialidade, é que o episódio da "Vaza Jato" tenha causado tanto alvoroço [para além, é claro, do fato em si, de ter revelado a intimidade e a cumplicidade da relação entre ministério público e magistratura, durante a operação Lava Jato, que repercutiu na prisão, às vés-

\footnotetext{
7 O superego é um elemento estrutural do aparelho psíquico, responsável pela imposição de sanções, normas e padrões. É considerado como sendo a agência moral e crítica da mente. Seria um "juiz implacável que frequentemente tem o poder de dominar, controlar e destruir o ego com censuras ferozes e críticas depreciativas.". (Homrich, 2008, p. 12).

${ }^{8}$ Marcel Mauss (2009, p. 325 e 335), sociólogo e antropólogo francês, tem um texto muito interessante - intitulado "a expressão obrigatória dos sentimentos (rituais orais funerários australianos)" - que me serviu de inspiração para pensar as questões aqui colocadas, mas que, por ora, optei por não enfrentar. Mas, apenas para pontuar, ele trata os sentimentos como fenômenos sociais, não exclusivamente individuais e subjetivos; não espontâneos, mas obrigatórios, ritualizados, previsíveis. Segundo ele, nos rituais funerários australianos, é preciso expressar determinados sentimentos. Existem manifestações sensíveis obrigatórias, expressas por pessoas encarregadas de explicitar pesar. O texto é especialmente curioso, porque mostra que os sentimentos manifestados nesses rituais, por serem obrigatórios, não são necessariamente genuínos, mas ao olhar externo, precisam ser expressos. Segundo Mauss, esses rituais não excluem necessariamente a sinceridade, mas preveem, por exemplo, uma "quantidade convencional de choros e de gritos" (2009, p. 330). A leitura ajuda a entender as formas de interação social naquele grupo e, tangencialmente, permite fazer um paralelo com os sentimentos do Judiciário e sua expressão obrigatória por parte dos magistrados.
}

peras da eleição, do ex-Presidente da República, Luiz Inácio Lula da Silva].

De todo modo, o que me interessa pontuar aqui [sem minimizar, de forma alguma, os efeitos da atuação do ex-Juiz Sergio Moro] é justamente que a intensidade da perplexidade com o fato ocorrido tem relação direta com a proporção da crença.

Ou seja, explicitar [ou tratar] como absurda, incomum, inédita ou extraordinária a conduta do juiz que conduziu o processo da operação Lava Jato é, de um lado, desconsiderar a realidade processual brasileira, e, de outro, manter viva a crença em um conceito de imparcialidade inexistente [e sem correspondência com a realidade].

Na ocasião da pesquisa para o doutorado, entrevistei um juiz curioso, que demonstrou muita satisfação em me receber e se mostrou bastante disponível para dialogar sobre temas de interesse da magistratura, e que me disse: "No fundo, na verdade, a coisa funciona meio como um teatro de máscaras...é meio uma persona que você cria, porque você precisa passar confiança para aquelas pessoas.".

Um outro juiz, aposentado, escreveu um ensaio, que virou um livro, intitulado "A parcialidade dos juízes", que, ao mesmo tempo em que explicita a sua descrença na imparcialidade judicial, descreve a necessidade de mantê-la aparente: "[...] a imparcialidade não basta por si mesma, mas precisa se mostrar também em sua aparência. Ela é praticamente tudo o que a justiça pode oferecer para ganhar a confiança e a credibilidade dos jurisdicionados.". (Araújo, 2002, p. 21).

Um advogado experiente que entrevistei também afirmou que: "a imparcialidade serve como um véu de uma aparente ho- 
nestidade intrínseca à sua estrutura.".

Khalil (2011, p. 130), autor de um livro muito interessante sobre a personalidade dos juízes e a importância de seu perfil na condução do processo, citando uma audiência, menciona que a juíza do caso teria sido chamada de você e manifestou que preferia ser tratada como senhora, dizendo, expressamente: "afinal, não somos amigas, sou uma magistrada". Depois, segundo ele narra, a magistrada teria se justificado, dizendo: "a formalidade existe na Justiça e tem um sentido, que é a imparcialidade. Claro que há outros sentidos, mas para mim o principal é o da imparcialidade, manter uma distância aparente das partes.".

Uma desembargadora me contou uma história interessante uma vez:

Uma vez, eu era juíza em Volta Redonda, faz bastante tempo já. Era uma busca e apreensão de uma criança. Aí, a porta da sala de audiências estava aberta [...] Eu fui advogada de um banco antes de ser magistrada. E esse banco tinha vários advogados credenciados no interior e esse advogado, que eu vou te contar, era credenciado em Angra dos Reis, ali perto. Então, eu o conhecia. Ele estava do lado de fora da audiência e ele sabia que eu era magistrada lá. Aí, ele me viu: ‘Oi [e me chamou pelo nome]. Você tá boa, tudo bem? Quanto tempo etc, etc...' Me cumprimentou calorosamente. Parecíamos amigos íntimos. Aí, ele acabou de falar e foi embora. Tudo bem. Cumprimentei e, enfim, tudo bem. Aí, quando eu chamo a audiência da brigalhada da guarda das crianças, adivinha? Ele era advogado de uma das partes. Aí, quando todo mundo sentou, eu esperei, e falei assim: 'Olha, quando abriu a porta aqui da sala de audiências, o Doutor me cumprimentou animadamente, divertidamente, e eu quero esclarecer da onde que eu o conheço. Eu o conhecia assim e assim e assado. Ele era advogado externo do banco em que eu trabalhava e ele ia lá, prestar contas do trabalho etc. Eu não tinha amizade pessoal com ele e quero esclarecer. E realmente, pensa bem? Do jeito que a pessoa fala, às vezes parece isso, né? Que você tem a maior intimidade...e não era o caso. Não éramos velhos amigos...Então, eu esclareço sempre essas coisas. Com a intenção de que as pessoas vejam claramente o que está acontecendo. E acho que isso é que deixa tudo claro. Para dar transparência de imparcialidade. Sempre tenho essa preocupação de não apenas ser, mas também de parecer imparcial. Isso é muito importante no Judiciário.

Nesse sentido, o dever de "parecer imparcial" surgiu, nas falas dos entrevistados, como uma obrigação, que, ao mesmo tempo em que é necessária, os oprime, funcionando como uma espécie de "superego", que doma ou reprime [para controlar] os "instintos" dos magistrados.

Foi comum nas falas, ouvir que "seja na sentença, seja na audiência, as opiniões e as emoções do juiz são conteúdos guardados".

Khalil (2011, p. 293), em sua pesquisa, entrevistou um juiz que falou literalmente sobre a blindagem que a magistratura impõe. Segundo ele, o juiz tem de ficar muito "recolhido" e isso, inclusive, o "inibe". Para ele, "o juiz é um ser naturalmente comedido, discreto, reservado, como se isso o liberasse de ter os conflitos pessoais, que ele tem, em cada processo.".

Escutei, muitas vezes, repetidamente, du- 
rante o trabalho de campo, a frase: "nós somos seres humanos", como se esse sistema que funciona como "superego" restringisse a sua própria condição humana (afligindo-os).

Um juiz substituto, bastante jovem, que eu entrevistei me disse como sentia essa autocontenção:

Quando eu entrei para a magistratura, fiquei muito assustado com a expectativa que as pessoas criavam sobre mim... assim, de que eu tenho um conhecimento enorme, que eu sei tudo, que eu não erro. Isso me deixou apreensivo. $\mathrm{E}$ isso da imparcialidade me oprimia também, porque eu tinha que ser quase de outro planeta. Mas nós não somos heróis, nem somos de outro planeta. Erramos, temos medo, temos insegurança, temos pena, temos tudo que todo mundo tem. Mas isso ficava na minha cabeça, pressionando. Era horrível no começo. Eu sofri...depois, com o tempo você vê que as coisas não são bem assim.

E um outro falou: "é impossível não se jogar pra dentro de si na hora de decidir. Impossível.".

Um outro juiz que entrevistei, disse-me: "toda decisão absorve o emocional de quem a profere. Somos humanos. Há causas que a carga emocional é enorme, só que essa carga não pode se conflituar com a lei e nem pode ser escancarada.".

Percebi, no trabalho de campo, que, ao mesmo tempo em que os magistrados, durante as entrevistas e em manifestações públicas, nos julgamentos e audiências que assisti na ocasião da tese, tentavam demonstrar que o processo é racional, objetivo, e a imparcialidade judicial Ihes impede de acessar o seu subjetivismo e o seu lado humano, a fim de evitar a "contaminação" da análise dos autos processuais, também ficava clara para mim a percepção de que este fim Ihes era muito penoso e de difícil acesso, porque, "enquanto seres humanos", eles acabavam, querendo ou não, se valendo de suas emoções e agindo de forma nem sempre racional.

Uma juíza me disse uma vez: "O maior dilema é o seguinte: você não pode julgar com o coração. A sua referência é a Lei. Mas só que você tem um coração. E faz o que com ele?".

\section{ENTRE A NEUTRALIDADE E A IMPARCIALIDADE}

Nesse ponto, é que surgiu, durante o trabalho de campo, uma reação dos entrevistados em relação a um conceito doutrinário, bastante retórico, que tenta distinguir os conceitos de neutralidade e de imparcialidade, e que, nas entrevistas, não se sustentou.

A distinção, pouco palatável, pareceu mais discursiva do que empírica. Eis o discurso doutrinário:

[...] Não se deve achar, porém, que a exigência de imparcialidade esteja ligada a uma suposta exigência de neutralidade do juiz. Em primeiro lugar, tal neutralidade é absolutamente impossível, uma vez que o juiz, como qualquer se humano, exerce seu trabalho embasado em razão e emoção. O raciocínio do juiz tem necessariamente premissas que só ele conhece inteiramente, as quais têm índole ideológica, cultural, econômica, religiosa etc. Além disso, o juiz, como qualquer ser humano, pode ser tentado a favorecer aquele que se mostra mais simpático, ou mais fraco. A imparcialidade que se exige, porém, nada tem a ver com essas obviedades [...] O juiz deve ser imparcial sem 
ser neutro [...] A imparcialidade que se espera do juiz é a que resulta da ausência de qualquer interesse pessoal do juiz na solução da demanda a ele apresentada. Não se pode admitir que um processo seja submetido a um juiz ligado a alguma das partes por laços de parentesco ou amizade (ou mesmo de inimizade), ou que tenha interesse, econômico, jurídico ou de outra ordem, na vitória de qualquer das partes. $O$ juiz deve ser estranho às partes [...] (Câmara, 2006, p. 45 e 46).

Há, com efeito, propensão bastante difundida a identificar dois conceitos: o de imparcialidade e o de neutralidade. Trata-se, a meu ver, de grave equívoco. Dizer que o juiz deve ser imparcial é dizer que ele deve conduzir o processo sem inclinar a balança, ao longo do itinerário, para qualquer das partes [...] outra coisa é pretender que o juiz seja neutro, no sentido de indiferente ao êxito do pleito. Ao magistrado zeloso não pode deixar de interessar que o processo leve a desfecho justo [...] (Barbosa Moreira, 2001, p. 29)

Eis a premissa que orienta: a imparcialidade não exige que o juiz seja neutro. $\bigcirc$ juiz, segundo destaca Martins (2007):

[...] não é um ente alheio ao mundo [...] no seu dia-a-dia ouve boatos sobre os casos que irá julgar, possui opiniões pré-formadas sobre determinados âmbitos da realidade que podem vir a constituir-se objeto de seu julgamento [...] todavia, não se torna parcial [...] ao contrário, para que o juiz possa ser imparcial deve estar atento ao mundo ao seu redor [...] a desumanização seria uma exigência da neutralidade, mas não da imparcialidade. (Martins, 2007, p. 64 e 65)
Ocorre que, nas entrevistas, essa distinção se mostrou muito complexa de ser atingida pelos atores do sistema de justiça. [...] é muito cômodo esse discurso de se esconder atrás de uma suposta neutralidade.". "Essa discussão é retórica. Na prática, não faz sentido.".

Os juristas adoram essa distinção retórica: 'Ah, somos todos imparciais, mas jamais neutros, porque somos humanos.'. Ora, exatamente porque somos humanos é que não temos como ser nem neutros nem imparciais. Isso é um jogo de palavras que não funciona. Serve para aquietar os juristas, mas, no mundo real, não explica nada. Nós não temos como ser nem neutros, nem imparciais.

A neutralidade, segundo revelaram os dados empíricos, seria impensável, porque constituiria a ausência de valores. "Neutro ninguém é. Impossível ser", disseram-me alguns interlocutores.

A fala de uma juíza com quem conversei também é expressiva disso (e, igualmente, da confusão [e da ausência de distinção conceitual clara] que normalmente meus interlocutores faziam entre as categorias imparcialidade e neutralidade): "Falar em imparcialidade é muito complicado, porque você não é uma pessoa que não tem nenhuma opinião anterior. Você não é um quadro em branco, que decide só com a argumentação que as partes informam no processo. Isso não é verdade.".

Uma decisão judicial que eu li, em uma exceção de suspeição de magistrado que consultei, também confunde os termos imparcialidade e neutralidade: "A imparcialidade do juiz é uma das maiores garantias que decorre do Estado Democrático de Direito e da cláusula do devido processo legal formal. 
Sob a atuação do juiz não deve pairar qualquer dúvida acerca de sua neutralidade". ${ }^{9}$

A costura dos dados de campo leva esse tema [relacionado à distinção meramente retórica entre os conceitos de neutralidade e de imparcialidade] ao seguinte ponto - e último que pretendo discutir neste artigo: trata-se da percepção de que a distinção entre neutralidade e imparcialidade perde o sentido em um sistema de justiça que acomoda o contraditório de interpretações legais e que não controla a igualdade no tratamento dos casos concretos, permitindo que casos idênticos sejam julgados de forma diferente e que leis sejam interpretadas sem critérios consensuais, autorizando o juiz a julgar "como ele quiser" [ou na linha da orientação interpretativa que ele escoIher, para "fazer justiça"].

\section{6. "FAZER MÁGICA" PARA "FAZER JUSTIÇA"}

Às vezes, "fazemos mágica" para "fazer justiça". Ouvi mais de uma vez essa frase nas entrevistas que fiz.

E um exemplo do que menciono aqui, pode ser também percebido na fala de uma magistrada de vara criminal que entrevistei. Ela havia sido juíza cível durante longo período de sua carreira e acabou sendo titularizada em vara criminal. E me relatou o seguinte:

[...] me recordo de um caso marcante em um processo criminal. Eu não queria prender o cara. Eu não queria que ele voltasse a cumprir uma pena. Ele já tinha cumprido a pena do primeiro processo dele. Ele até tinha respondido ao processo e tinha ficado um bom tempo preso. E eu não queria que ele voltasse a cum- prir uma pena. Eu não queria, não queria que ele voltasse. Aí, entra toda a questão dos valores do juiz, de como você pensa, do que que você acha, daquilo que você acredita. Porque tem juiz que acha que quanto mais rigor na aplicação da pena, melhor [...] ou você pode ter um juiz como eu, que não acredita muito em pena de prisão e aí no que pode, no que consegue, tenta manter as pessoas fora da cadeia [...] eu fiz um exercício enooooorme para conseguir substituir a pena desse infeliz. Eu fiz todo um exercício de argumentação. Eu não queria prender o cara.

Uma desembargadora cível que entrevistei, comentando uma decisão judicial que concedia transporte gratuito para um cidadão realizar o seu tratamento de saúde, excepcionando as hipóteses legais de gratuidade, me disse o seguinte:

Nós fizemos mágica aquele dia para dar àquele cidadão o que ele pleiteava. Agora já tem muitos precedentes e a questão está pacificada aqui no TJ. Mas, quando decidimos pela primeira vez, criamos uma tese com base no direito fundamental à saúde, no princípio da dignidade da pessoa humana, e demos o que ele pedia e o que nós queríamos. Ele tinha câncer.

Uma promotora cível com quem eu conversei, me explicou que o juiz só pode trabalhar com o que "está no processo". Mesmo que ele tenha de se "afastar de sua convicção", o mais importante é que ele "cumpra a lei, mesmo que ele discorde dela". Ela disse ser comum "o feeling do juiz indicar que a justiça está em um lugar, mas a lei apontar para o outro", casos em que ele tem de "cumprir a lei". No entanto, segundo ela me disse, apesar de esta ser a "regra", "é sempre possível que o juiz feche os olhos para uma for- 
malidade ou outra". Tudo, em suas palavras, "pelo bem maior da justiça".

Ela me disse que ser "legalista" é uma tendência cada vez mais escassa, o que, em sua visão, é muito "bom". Ela disse que em determinadas situações é possível "dar uma voltinha aqui e outra ali para fazer justiça.".

Quando eu pedi exemplos concretos, ela me falou:

A lei não é dinâmica como a realidade. Então, para acompanhar a realidade da vida, os juízes têm de ser criativos, construir novas formas de interpretar essa lei, que fica ali parada, estagnada, sem acompanhar a sociedade. Então, por exemplo, a guarda compartilhada. ${ }^{10}$ A guarda compartilhada surgiu da prática. Os juízes inventaram isso. E agora tem a lei [Lei $n^{\circ} 11698 / 2008$ ], que veio regular o que os juízes vinham decidindo no dia a dia. Diante das situações que eles tinham de julgar, eles começaram a construir essa ideia. Não tinha lei. Se a gente for pensar, eles julgavam contra a lei. Agora tem. Mas antes não tinha. Em vara de família, em geral, a gente vê que o tempo todo, os juízes rasgam o código. $E$ tem de rasgar mesmo. Tem de ver, no caso concreto, o interesse da criança, - melhor pra ela. Por exemplo, visitação de padrasto....isso não tá na lei. De avó de criação...e eu já vi conceder. Então, é tudo muito subjetivo. É subjetivo mesmo. Por isso que essa tal da imparcialidade...hum... não dá para seguir isso sempre. O certo é: faz o que tá na lei e conforme a prova dos autos. Mas nem sempre isso é possível. A gente dá um jeito, estica daqui e dali, para fazer justiça. (grifou-se)

\footnotetext{
${ }^{0}$ A guarda compartilhada é distinta da guarda unilateral. A guarda unilateral é atribuída a um só dos genitores após a separação. Já a guarda compartilhada significa a responsabilização conjunta e exercício de direitos e deveres do pai e da mãe que não vivam sob o mesmo teto, concernentes ao poder familiar dos filhos comuns.
}

Muito tempo depois, quando eu estava quase indo embora, a promotora me narrou um caso vivenciado por ela.

Bom, a gente brinca que o MP no cível é o palpiteiro de plantão, né? Porque a gente dá parecer, então, sugere que o Juiz julgue de um jeito ou de outro. Houve um caso, que foi assim. A filha ajuizou uma ação para reclamar contra a seguradora de saúde do atendimento de home care que era prestado ao seu pai. Segundo ela, as enfermeiras eram péssimas, despreparadas e insensíveis. Quando li, quase chorei. O pai era velhinho, tinha noventa anos...aí, na inicial ela dizia que as enfermeiras eram ruins. $\mathrm{Na}$ contestação, a seguradora dizia que ela que era uma pessoa muito difícil, ruim de trato, grosseira. Bom, no contrato não vem dizendo que a seguradora tem de oferecer enfermeiras sensíveis e gentis, né? Manda prestar o serviço de home care e ponto final. E isso a seguradora prestava. Aí, o meu juiz marcou a audiência [é comum o promotor se referir ao juiz da vara onde é titular como "meu" ou "minha"]. No dia da audiência a gente viu que a filha era uma coisa. Insuportável... aquelas pessoas que pensam que vão ganhar no grito, sabe? Eu fiquei até com raive dela. Aí, eu te falo. Promotor é imparcial? Sendo sincera com você, quase dei o parecer contra. Fiquei com raiva dela. E era mais fácil dar o parecer contrário, até porque o contrato não dizia que a seguradora tinha que enviar enfermeiros bonzinhos. Fala que tem de prestar o serviço enviando enfermeiros de formação. Isso, a empresa fez. Então, era até mais fácil dar o parecer contra ela. Mas aí pensei. Poxa, é o pai dela. Ele não tem nada com isso...e aí, esticamos daqui e dali, eu e meu juiz conversamos, pensamos, juntos...decidimos um pouco contra o contrato, porque eu dei o parecer e ele acolheu, no 
sentido de compelir à seguradora a fornecer enfermeiros cuidadosos, enfim, isso não tá no contrato, nem na lei, mas, e a verdadeira justiça? O TJ vai manter essa loucura que a gente fez? Sei lá. Mas acontece esse tipo de coisa...

"Pra mim, o juiz não é imparcial nunca. Ele vai usar o que quiser pra julgar daquela maneira que ele quer.", me disse uma defensora pública.

Khalil (2011, p. 160) também entrevistou magistrados que manifestaram essa possibilidade. Um deles, admitindo que o ordenamento jurídico é extremamente aberto, lhe disse: "O juiz pode decidir do jeito que quiser, que encontrará de algum modo amparo no ordenamento.". E exemplifica: "O STJ inventou que cabia prisão na hipótese de inadimplemento das três últimas pensões [alimentícias]. Nunca segui, porque é uma tremenda besteira.".

Outro magistrado the disse que, em determinados casos, quando lê a inicial, ele acha que o autor tem razão, mas, depois, ao ler contestação, fica em dúvida e acaba fazendo o que "quer" (Khalil, 2011, p. 303): "Aí você vai adotar as suas premissas [...] e você faz o que você quer.".

E outro confirmou o mesmo (Khalil, 2011, p. 314): "Eu sempre falei: 'o juiz faz o que ele quer, faz o que ele quer' [...]”.

José Renato Nalini (2019), em seu ensaio sobre a "Humildade do Juiz", ${ }^{11}$ também expressa:

O juiz sabe que ele julga como quer. É fácil encontrar argumentos contra ou a favor de qualquer das teses. Fundamental se torna a sua profunda honestidade in-

\footnotetext{
"Disponível em: <https://emeron.tjro.jus.br/images/biblioteca/revis tas/emeron/revista-emeron-2005-13.pdf>. Acesso em 22 abr. 2020.
}

telectual, fomentada pela humildade intelectual, para que, no ato de julgar, não prevaleçam as idiossincrasias, os preconceitos, o comodismo ou qualquer outro subjetivismo, sobre a missão de fazer justiça. (Nalini, 2019, p. 11 e 12)

É recorrente, durante o curso de direito, ouvirmos que "em direito, em 99\% dos casos, você tem fundamento pra todos os lados.".

Somos formados a partir da lógica de que "você sempre acha uma resposta para a sua pergunta.". Nesse cenário, a liberdade de decidir o que é justo, ou não, é praticamente absoluta e incontrolável: "você decide o que é justo e vai atrás do fundamento. Você vai achar", me disse um magistrado.

Uma promotora de justiça com atuação cível me disse: "ter essa elasticidade toda na Lei é muito bom, porque você puxa daqui, puxa dali, esgarça a lei e enfia tudo o que você quiser ali dentro. Cabe tudo.".

A ausência de consenso oficial sobre o conteúdo da lei concede aos magistrados - ou melhor, deles exige - que preencham os vazios. E o nosso sistema está cheio de vazios de consenso e, por conseguinte, cheio de significados diferenciados para situações semelhantes.

Logo, o juiz, o tempo todo, na condução do processo e no momento de decidir, se vê diante da necessidade de preencher e de ocupar esses espaços vazios criados por um sistema fundamentado em abstrações, contradições e ambiguidades, em vez de consensos.

Quando digo e demonstro, através dos dados etnográficos, que, diante de uma situação concreta, os juízes "fazem o que eles querem", não pretendo, com isso, estigma- 
tizá-los, hostilizá-los ou confrontá-los, mas, simplesmente, porque entendi (e pretendo explicitar) que o sistema não Ihes dá outras saídas. E que, portanto, nos termos utilizados por Duarte (2010, p. 93), “a toga não está orquestrada em um complô contra a sociedade, mas exerce os poderes oriundos de um sistema que transforma esses juízes em personagens centrais e absolutos, inclusive, no momento de manifestarem suas vontades".

Um advogado me disse: "Não vejo outra forma de os juízes atuarem nesse sistema, senão escolhendo o lado que vai ganhar segundo suas próprias subjetividades. Um sistema operado por humanos não pode ser imparcial e nem neutro.".

A afirmativa de que "os juízes fazem o que eles querem" tem também outro sentido nesta tese: o de que eles fazem as suas escolhas segundo sua percepção pessoal sobre o que é justo. $E$, portanto, pensar em um sistema neutro ou imparcial é idealizar e sublimar o que a empiria revela ser inviável. É transformar em crença um discurso que não tem correspondência empírica.

"Fazer o que quer" significa decidir segundo uma convicção pessoal sobre o que parece ser o mais justo diante de determinada situação.

E isto é permitido porque o sistema não está permeado por padrões, protocolos e consensos. Cabe, a cada um, individualmente, e contraditoriamente, preencher de significados e representações o conteúdo da lei, da prova, dos fatos, da doutrina, do processo, da verdade.

Durante o trabalho de campo, foi comum ouvir falas como esta, de um magistrado:

Juiz pode, em alguns casos, acho que tender para um lado ou para o outro, visando a fazer Justiça, na medida em que existem muitas decisões divergentes. Então, se a parte tem, ou a gente sente que ela tem, um direito, mas às vezes o advogado dela não está conduzindo bem o processo, nesse sentido, às vezes, a gente atua com uma certa parcialidade, no sentido de buscar uma decisão dentro da lei, dentro dos limites da lei, se existe uma fundamentação numa outra direção que possa realmente vir a beneficiá-la, porque aí, pessoalmente, a gente está vendo que a parte é que está com a razão, entendeu? E é uma questão de Justiça e, então, nesse sentido, a gente pode até tender realmente mais para um lado do que para o outro, no sentido de buscar uma decisão favorável. Se a parte não demonstrou o seu direito, mas a gente percebe que ela tem o direito, a gente dá a ela uma decisão favorável, usando a jurisprudência para isso.

"Cada intérprete afirma o sentido da norma jurídica que the parece apropriado conforme seus próprios valores e partir de sua visão pessoal de mundo. Assim, não se pode considerar que dada interpretação é certa ou errada.". (Câmara, 2007, p. 86)

E uma juíza entrevistada confirma:

Tudo tem a ver com a percepção que a gente tem da lei. Para mim, a lei só é posta no mundo como norma quando o juiz ele interpreta e aplica ela ao caso concreto. Nesse caso, a lei se aplica dessa maneira, naquele, de outra e de outra, e assim sucessivamente. De acordo com a percepção de cada um, você pode dar uma interpretação diferente. $E$ isso não vai eliminar nunca. Nem com súmula vinculante nem com nada. A percepção 
de quem tá julgando nunca vai ser igual. E esse pluralismo de ideias é bom. Essa mistura de coisas, divergências de pensamento, tudo isso é muito bom, porque não permite a estratificação de um dogma. E cada caso é um caso [...] faz parte do sistema. E é assim...um perde aqui, outro ganha lá...é impossível que as pessoas pensem igual.

Uma promotora me disse que já viu várias vezes que: "o mesmo processo permite que o juiz julgue para qualquer lado. Eu faço parecer e vejo isso sempre. O mesmo processo permite que você ande pra qualquer lado: do autor ou do réu. Interpretar de um jeito ou do outro só depende de você".

Araújo (2002, p. 61) sustenta: "sabe-se que muitas causas tanto podem ser julgadas procedentes como improcedentes, ensejando razoável fundamentação, em ambas as hipóteses".

Em todo o período da tese, ouvi de muitos interlocutores que, em quase todos os casos levados ao Judiciário, é possível, racionalmente, julgar o mesmo processo procedente ou improcedente. E, quando eu questionava, o que muda esse resultado, eles diziam, "apesar de o sistema ter de ser imparcial", o que muda "é a percepção de quem julga", logo, o senso de justiça particular de quem decide.

\section{CONSIDERAÇÕES FINAIS}

Nessa linha, a postura do ex-Juiz Sergio Moro, comprometida por suas convicções pessoais e sensos particularizados de justiça [e não estou nem absolvendo-o, nem condenando-o], no tratamento e na condução da operação Lava Jato, apontando, inclusive, sua relação pessoal com o ministério público, não é inédita, nem extraordinária; é recorrente no sistema de justiça.

Sentenças proferidas por juízes comprometidos por moralidades e intenções particulares que interferem na jurisdição prestada, porque permeadas por possibilidades interpretativas incontroláveis, são proferidas diariamente em nosso sistema de justiça.

E a pesquisa que respaldou a minha tese de doutorado, aqui muito recortada, explicita que as práticas judiciárias e as decisões judiciais são orientadas por percepções subjetivas dos operadores e por suas interpretações pessoais sobre a lei, os fatos e as provas produzidas no curso do processo judicial.

Entre o dever de parecerem imparciais e o fato de serem humanos, o trabalho revela que os magistrados transitam em um sistema de crença na sua própria imparcialidade, construída discursivamente pelo campo do direito e que funciona como uma categoria estruturante do sistema judiciário.

Nesse sistema, o que permite e reforça o exercício arbitrário do poder de decidir conflitos a partir de critérios casuísticos é a ausência de consenso sobre o significado das leis, que desloca para o juiz o poder de interpretar e de decidir, no caso concreto, qual é a melhor solução ou "a mais justa" para a lide. Sendo assim, os dados são reveladores de que os resultados dos processos judiciais estão comprometidos e imbricados com os sensos de justiça particulares dos profissionais do direito que os conduzem.

Os dados coletados no trabalho de campo demonstram, ainda, e finalmente, que os juízes conduzem e decidem os processos judiciais a partir de moralidades que servem mais para justificar a parcialidade que exercem do que propriamente para reforçar o seu papel de julgador imparcial. 
Nesse diapasão, o comportamento do ex-Juiz Sergio Moro na condução dos processos da operação Lava Jato não se apresenta como extraordinário ou incomum, mas sim como revelador de uma lógica e de uma cultura jurídica que centraliza no Juiz as escolhas sobre fatos, evidências, verdades, leis, interpretações e sensos particularizados de justiça. O ex-Juiz Sergio Moro e a operação Lava Jato são, portanto, a mais pura explicitação do sistema de justiça brasileiro.

\section{REFERÊNCIAS}

Amorim, M. S. de. (2006). Juizados especiais na região metropolitana do Rio de Janeiro. Revista da Seção Judiciária do Rio de Janeiro - SJRJ, 17(2), 107-131.

Araújo, F. F. de (2002). A parcialidade dos juízes. Campinas: Edicamp.

Barbosa Moreira, J. C. (2001). Temas de Direito Processual: sétima série. São Paulo: Saraiva.

Berman, H. J. (2006). Direito e Revolução: a formação da tradição jurídica ocidental. São Leopoldo, RS: Editora UNISINOS.

Bourdieu, P. (1983). O que falar quer dizer. In. P. Bourdieu. Questões de sociologia. (p. 112-121). Rio de Janeiro: Marco Zero.

Bourdieu, P. (1989). O Poder Simbólico. Rio de Janeiro: Bertrand Brasil.

Brasil (2015). Lei n 13.105, de 13 de março de 2015. Código de Processo Civil. Diário Oficial da União, Brasília, 16 mar. 2015.

Brasil (1940). Decreto-Lei $n^{\circ}$ 2.848, de 07 de dezembro de 1940. Código Penal. Diário Oficial da União, Rio de Janeiro, 31 dez. 1940.

Câmara, A. F. (2006). Lições de Direito Processual Civil. $15^{\mathrm{a}}$ ed. Rio de Janeiro: Lumen Juris.

Câmara, A. F. (2007) Ação Rescisória. Rio de Janeiro: Lumen Juris.
CNJ. Conselho Nacional de Justiça (2008). Código de Ética da Magistratura Nacional. Aprovado na $68^{a}$ Sessão Ordinária do Conselho Nacional de Justiça, do dia 06 de agosto de 2008, nos autos do Processo $n^{\circ}$ 200820000007337. Diário de Justiça, Brasília, 18 de setembro de 2008. Disponível em: < https://www.cnj.jus. br/codigo-de-etica-da-magistratura/>. Acesso em 22 abr. 2020.

Diniz, M. H. (1994). Compêndio de introdução à Ciência do Direito. 6a ed. São Paulo: Saraiva.

Duarte, F. (2010). A construção da verdade no processo civil e a igualdade jurídica. In: F. G. M. Netto; D. R. S. Meirelles (Orgs.). Direito Processual em debate (p. 91108). Niterói: Editora da UFF.

Duarte, F.; lorio Filho, R. M. (2015). A lógica do contraditório: ainda somos medievais. In G. S. Siqueira; A. C. Wolkmer; Z. L. Pierdoná. (Orgs.). História do direito (p. 1-23). Florianópolis: CONPEDI.

Foucault, M. (1971). Resposta ao círculo epistemológico. In: M. Foucault et al. (Org.). Estruturalismo e Teoria da Linguagem (p. 9-55). Rio de Janeiro: Tempo Brasileiro.

Foucault, M. (2005). A ordem do discurso. São Paulo: Edições Loyola.

Galdino, F. (2011). Imparcialidade judicial. In: F. Galdino, R. Lobo Torres, E. T. Kataoaka (Orgs.), Dicionário de Princípios Jurídicos (p. 539-588). Rio de Janeiro: Elsevier.

Geertz, C. (1998). Do ponto de vista dos nativos. In: C. Geertz. O Saber Local. (p. 85-110) Petrópolis: Vozes.

Greco, L. (2005). Estudos de Direito Processual. Campos dos Goytacazes, RJ: Editora Faculdade de Direito de Campos.

Homrich, A. C. B. (2008). O conceito de superego na teoria freudiana. Tese (Doutorado em Psicologia) - Instituto de Psicologia da Universidade de São Paulo, São Paulo, Brasil.

Jeveaux, G. C. (1999). A simbologia da imparcialidade do juiz. Rio de Janeiro: Forense.

Kant de Lima, R. (2010). Sensibilidades jurídicas, saber 
e poder: bases culturais de alguns aspectos do direito brasileiro em uma perspectiva comparada. Anuário Antropológico, v. 2009(2), 25-51. DOl: https://doi. org/10.4000/aa.885

Khalil, A. A. (2011). A personalidade do juiz e a condução do processo. São Paulo: Ed. Antoin Abou Khalil.

Lévi-Strauss, C. (1976). A noção de estrutura em etnologia. São Paulo: Abril cultural.

Lopes Júnior, A. (2016). Fundamentos do Processo Penal. Introdução Crítica. São Paulo: Saraiva.

Lupetti Baptista, B. G. (2013). Paradoxos e ambiguidades da imparcialidade judicial: entre "quereres" e "poderes". Porto Alegre: Sergio Antonio fabris - safE.

Martins, J. R. S. (2007). O Dogma da Neutralidade Judicial: sua contextualização no Estado brasileiro contemporâneo. Rio de Janeiro: Editora Lumen Juris.

Mauss, M. (2009). A expressão obrigatória dos sentimentos (rituais orais funerários australianos). In: $M$. Mauss. Ensaios de sociologia (p. 325-335). São Paulo: Perspectiva.

Nalini, J. R. (2019). A humildade do Juiz. Roraima. Disponível em: < https://emeron.tjro.jus.br/images/biblioteca/ revistas/emeron/revista-emeron-2005-13.pdf>. Acesso em 15 nov. 2019.

OEA. Organização dos Estados Americanos (1969). Convenção Americana de Direitos Humanos ("Pacto de San José de Costa Rica"). Disponível em: <http://www. oas.org/juridico/portuguese/treaties/b-32.htm>. Acesso em 22 abr. 2020.

ONU. Organização das Nações Unidas (1948). DUDH - Declaração Universal dos Direitos Humanos. Disponivel em: <https://nacoesunidas.org/wp-content/uploads/2018/10/DUDH.pdf>. Acesso em 22 abr. 2020.

Reale, M. (2004). Lições Preliminares de Direito. $27^{\mathrm{a}}$ ed. São Paulo: Saraiva.

Data de submissão: 18/11/2019

Data de aceite: 11/03/2020 